\title{
Responding for anxiety itself
}

Peter Warnek

Wenn es richtig bleibt, dass die Neurosen sich in nichts Wesentlichem von der Norm entfernen, so verspricht ihr Studium uns wertvolle Beiträge zur Kenntnis dieser Norm zu liefern.

$\sim$ Sigmund Freud ${ }^{1}$

Neurosis is the way of avoiding nonbeing by avoiding being.

$\sim$ Paul Tillich ${ }^{2}$

L'angoisse n'est pas le doute, l'angoisse est la cause du doute.

$\sim$ Jacques Lacan 3

The reading presented in this essay, which manages to interrogate only a few pages of Freud's text, is motivated by a question, claimed by the need to raise that question, as it concerns the relation between anxiety and responsibility. The reading carried out here should be taken, then, as an attempt at the elaboration of this question, perhaps even as a contribution to that elaboration, even though, as that reading progresses, it becomes only more preoccupied with only one single sentence found within the few pages it reads, by even then fixating, seemingly without justification, upon one peculiar phrase within that sentence, consisting of only three words. This phrase or locution, which finds its way translated into the title of this paper, takes the form of a reflexive construction, in which

\footnotetext{
${ }^{1}$ Abriss der Psychoanalyse. GW 17, 110. "If it holds true that neuroses are not in any essential way separated from the norm, then their study promises to yield valuable contributions to our knowledge of this norm." Since the Abriss is not included in the Studienausgabe, the citation refers to the Collected Works. Sigmund Freud, Gesammelte Werke (18 Bände), (Frankfurt am Main: Fischer Verlag, 1960).

2 Paul Tillich, The Courage To Be (New Haven: Yale University Press, 2014), 61.

3 "Anxiety is not doubt, anxiety is the cause of doubt." Lacan's well known claim that anxiety is "that which deceives not" is complicated by his assertion that doubt, uncertainty and deception in general arise from it. Here is the context of the assertion: "Tous les aiguillages sont possibles à partir de l'angoisse. Ce que nous attendions en fin de compte, et qui est la véritable substance de l'angoisse, c'est le ce qui ne trompe pas, le hors de doute. Ne vous laissez pas prendre aux apparences. Ce n'est pas parce que le lien peut vous paraître cliniquement sensible de l'angoisee au doute, à l'hésitation, au jeu dit ambivalente de l'obsessionnel, que c'est la même chose. L'angoisse n'est pas le doute, l'angoisse est la cause du doute." The passage in the English translation runs: "Things can branch off in every possible direction starting from anxiety. What we were waiting for, when all's said and done, and which is the true substance of anxiety, is that which deceives not, that which is entirely free of doubt. Don't let yourself be taken in by appearances. Just because anxiety's link to doubt, to hesitation, to the obsessional's so-called ambivalent game, may strike you as clinically tangible, this doesn't mean they are the same thing. Anxiety is not doubt, anxiety is the cause of doubt." Jacques Lacan, Le Séminaire, Livre X, L'angoisse (Paris: Seuil, 2004), 92. Anxiety, The Seminar of Jacques Lacan, Book X, ed. Jacques-Alain Miller, trans. A. R. Price (Malden: Polity Press, 2014), 76.
} 
a definite or proper subject matter (namely, the anxiety or die Angst) comes to be immediately repeated, reiterated and redoubled as itself, by means of an intensifying pronoun which refers back to it, in the role of an emphatic appositive. The reflexivity of this apposition would emphasize and reinforce its already enunciated subject. And, in this reflexive intimacy, in its utter proximity to itself, which also refuses to become an identity, anxiety is brought to expression, being expressed only in relation to itself, compounded through this difference or distance which would structure and allow for its own tautology, according to that logic which lays claim to what is merely tav่ós by also relating it to itself in this difference from itself, but in an intensification in which it comes to insist upon itself, as what it is by being the same as itself, as what it itself would be if only it were to be nothing but itself, being called or qualified only through its own self-referral or selfdifferentiation, as what is called or named "the anxiety itself," die Angst selbst.

How, then, is this reading guided in advance by a concern with anxiety and responsibility, precisely as it attempts to discern what in particular would be demarcated or designated by Freud as he refers here cryptically and enigmatically to die Angst selbst? This reading results directly from this concern, from a desire to articulate it, to bring it to expression in a questioning, precisely as it struggles to clarify the sense of this phrase, to discover what it would hide within itself, even as it appears to refer only to itself, only by referring to itself, by referring only to anxiety itself. The entire issue here demands considering, with as much care and nuance as possible, why Freud finds it necessary to introduce this phrase and, further, what he accomplishes by introducing it in the way that he does.

The fact of the matter is that he makes use of this phrase as though he were already the sovereign master of what would be named with it or brought under it, without once ever having to account for it, without every assuming any responsibility for having to give any such account. He only gestures toward what is called anxiety itself, only invokes it in passing, almost gratuitously, so as to take possession of it in advance, precisely in order to set it aside, to leave it unaddressed. And, most decisively, only by means of this gambit or maneuver, only by means of its utterly irresponsible assumption, in which anxiety itself is dismissed, in which it is set aside by means of being taken for granted, as though it were 
already in itself transparent, already self-evident to everyone, is Freud first able to establish for himself a space for the posing of the problem of anxiety. The Freudian invocation and dismissal of anxiety itself, which feigns to speak of what needs no introduction only because it remains fundamentally unpresentable, marks the passage into the psychoanalytic problematizing of anxiety. It marks the beginning of that discourse which proceeds by first forgetting the anxiety of its position.

It is also worth noting that the concern of this essay, as it considers the fate of responsibility in Freud's treatment of anxiety, also belongs to and emerges from a prior and more comprehensive investigation which, by inquiry into the philosophical history of responsibility, would bring about a fundamental transformation of our given understanding of responsibility. Yet a detailed review of what results from this larger inquiry would take us far beyond the scope of this paper. We thus have to forego an elaboration of the sense of responsibility as it informs our questioning of Freud, except only to emphasize that this questioning depends upon sustaining the difference between anxiety and responsibility, since only from this difference can they be brought to bear upon each other. In bringing them to bear upon each other, we discover not only that anxiety must be altered in an assumed responsibility for it but something still more startling, that our responsibility is founded upon or constituted in an experience of anxiety. We discover that in our anxiety we are first called to our being responsible, and that there is no responsibility which is not continually claimed in this call by its anxiety, which does not already harbor within itself this anxiety. By giving a few brief indications of how this might be understood, my hope is that the engagement may allow the engagement.

As a matter of course, in our everyday world, we live under the assumption of a prior, given responsibility. Common sense even dictates that we take this responsibility for granted, that we have no choice but to assume in advance that we are already responsible, that we ourselves are already constituted in an undeniably given but still undecided responsibility. We come to ourselves, awaken to our own birth, to the inexplicable event of our own existence, only as we are born into the given fact or facticity 
of this responsibility, as we find ourselves claimed in advance by it, delivered over and exposed to it without recourse or any possible substitution.

We are born into this being responsible, into its facticity, even as we are also called to respond for ourselves from within it, as we are called to ourselves in this given responsibility, being already responsible for ourselves, for our own being. We are born into our own being responsible, into a given responsibility which is already calling for our response, by calling us to respond for ourselves in this being already responsible. We are born as the recipients and beneficiaries of this awesome inheritance, which has already imposed itself upon us before we ever respond to it or assume it. It has already been bestowed upon us, being already received by us, long before we are able to respond for it by assuming it. We are this being responsible before we assume it and can assume it only because we are, in our very being, already responsible.

In this prior, given responsibility, we find ourselves already given. We find ourselves first of all given to ourselves in this being already responsible, already given to ourselves in this given being, being already given. And only from the position of this being already given, as we find ourselves already responsible, being already able to respond, does any responsibility ever come to be assumed or become assumable. Only from this given position, from the position of this being which is already given, in which we find ourselves already able, in which this being able is already given, in which we are already responsible, being already endowed with this ability, do we ever presume to take possession or assume any ownership of this being able, by assuming a responsibility for our assumption of it. Only from the priority of this position, from which this responsibility is already given, in which it is already been given to us, are we ever in a position to take this given responsibility upon ourselves, by taking responsibility for ourselves in this position. And only from such a position would we ever dare to assign any responsibility to another.

In its utter priority - in which it remains anterior to every possible assumption of it - our given responsibility ensures that no response is ever given except as it is given in return, given in response to an open solicitation, in response to what calls for it, even when a response appears entirely uncalled for. This call neither necessitates nor causes 
what it can only call for. It does not coerce, does not obligate. It anticipates what it calls for but without having to impose prescriptions upon what would respond to it. By exceeding every possible response the call remains an open solicitation, receptive to what would still be given as a response to it, in return. In this openness, however, it also demands that the response come to itself by having to decide itself in its response, not merely by remaining able to respond, but by actually responding. And what allows for this decision, in calling for it, also grants to the response its ability to respond, by calling to its indecision and by allowing it to remain undecided in this being called. What calls for a response, as that response is allowed to respond from its own being able, also allows it to fail in its response. Responsibility is first granted in what allows for a response, by calling for it, but this allowance also shelters and preserves an original and ineradicable irresponsibility, as it is belongs to and is already harbored in every given ability.

But how are we to account for the vertiginous anxiety which takes hold of us in this call, as it awakens us to ourselves in this anxiety, in our having to assume our given responsibility, being already responsible for ourselves, for our own being given, being already called even before we are able to respond? It is true, we live in an age of both anxiety and responsibility. We know that we are already responsible and know that we are anxious, even as we still do not know what it is to be responsible and still cannot account for our own anxiety. We continue to speak irresponsibly of our anxiety, just as we affirm our being responsible only in this anxiety. Both anxiety and responsibility, as we know them, share the same very short history; they are both recent arrivals, both belong uniquely to our time, to the world we know as it has only just come into being over the last two and a half centuries. Remarkably, prior to our time, there was almost no talk of either responsibility or anxiety. To be sure, it can hardly be doubted that there is no responsibility without history. But we still have to grasp the more difficult truth, that there is also no history without responsibility, no history without that responsibility which awakens to itself in the measureless anxiety which calls for it.

In this way it becomes evident that the facticity or being of our given responsibility, that we are our ability to respond, cannot be grounded at all in the indeterminacy of an unconditioned arbitrium. So little does this facticity refer only to the caprice of an 
unconstrained "freedom" that it instead confronts us with the urgency of a question. We have to ask: how are we first able to respond when every response must begin in a prior receptivity, in a response-ceptivity to what first calls for it, to what enables it by summoning it to itself, by calling it to decide itself? A renewed inquiry into the experience of responsibility would not begin with a critique of its possible assumption, by attempting to reconstruct ex post facto the prior conditions of this possibility, but would begin from the already given facticity of its being, as this being precedes and outstrips every assumption of it, as it finds itself already delivered over to its own being given.

This inquiry would thus begin by having to venture two decisive and interrelated reversals or inversions, in order follow the displacements they unleash. (1) Responsibility must no longer be derived from a more original freedom but only in the experience of our being responsible does freedom become a question. (2) The first inversion precipates a second, since the response can no longer be grounded in a prior, given ability to respond, in the merely formal freedom which would first posit the response as a mere possibility before it becomes actual; instead, responsibility becomes able by responding, by arising from the response which is given only in response to what calls for it, in a responseceptivity to that call.

次次

Anxiety (itself) needs no introduction. Presenting it to you, placing it before you, serves no purpose, has no use. Its presentation would have no effect, would do no work.

Freud assures us and, by assuring us, he would reassure himself: each and every one of us is already familiar with anxiety, with "anxiety itself," with what it is itself, as itself and in itself - that is, as die Angst selbst. Without anyone ever telling us about it, without once needing to be told about it, we have on our own already become aware of it, have made its acquaintance. We have, each of us, at some point learned about it by ourselves, come to know it from out of ourselves, from what is our own, properly ours. It goes without saying, or almost without saying, every single one of us has at some time become acquainted on our own with this sensation or, to speak more correctly, this affective condition. 
And, owing to this universal, prior acquaintance, every possible presentation or representation of anxiety itself is made redundant, pointless, superfluous. Our given and assumed familiarity with anxiety itself renders such presentation needless: "Die Angst selbst brauche ich Ihnen ja nicht vorzustellen; jeder von uns hat diese Empfindung oder, richtiger gesagt, diesen Affektzustand irgend einmal aus eigenem kennengelernt" (FSA $1,380) .4$

Still, in this passage, which appears in his Introductory Lectures (1916-17), at the very beginning of the seminal lecture on anxiety, Freud does go to the trouble of introducing anxiety itself, despite insisting that it needs no introducing. More precisely, he goes to the trouble of introducing it, by taking it up thematically and naming it - even by way of rectifying a certain misnomer or misunderstanding with respect to it - but only in order to tell us that it needs no introducing. What we all might call a sensation (Empfindung) is instead an affect, is more properly an affective state or the condition of being affected; anxiety itself refers not to the reception of a sense-datum, or to any mere feeling, but, to speak more correctly (richtiger gesagt), to a way of being affected - that is, to a way of being claimed by and constituted in an affect (Affektzustand).

Freud thus averts a possible misrepresentation or misinterpretation of anxiety itself, even as he assures us that he has no need to introduce or present it to us, since each of us is already familiar with what goes by this name, with what is called anxiety itself. He anticipates what would be a mistaken understanding and takes measures to avoid it, by preemptively enacting this mistake and by pretending, if only for a moment, to misunderstand what everyone without further ado already knows. He misspeaks so as to demonstrate how to speak correctly or, at least, more correctly, in order to put into relief what anxiety itself more properly is, to clarify not only what it is as itself but also what it is not, what it would only appear to be, by being able to appear as something other than itself, other than anxiety itself. What we all know already, without needing any introductions or presentations, knowing it from out of ourselves, is introduced or presented by Freud at first incorrectly (or less correctly), namely, as a mere sensation, but

4 Throughout I am referring to the ten volume Studienasugabe of Freud's works published by Fisher Verlag (Frankurt am Main, 1969-1975). Hereafter FSA, followed by the volume and page number. All translations are my own. 
only in order to obviate a prevailing confusion, to counteract a predominant errancy in speech. He intervenes and sets us straight, by correcting himself, by correcting this performed slip of the tongue - that is, by first performing and then correcting his own parapraxis or Fehlleistung - even as he also insists that he has nothing to give us by which we would become better acquainted with anxiety itself, nothing to offer us in this regard that we do not already have, that we do not already know from out of our own experience or prior acquaintance with it.

And yet, Freud's need to identify and rectify this predictable misconception or errant tendency in speech, to forestall this possibility of misperformance, that we might readily think or speak of anxiety itself as a sensation and not as what it more correctly is, however else we might account for it, has no bearing on another need. It has no bearing on that need to introduce anxiety itself, no bearing on whether we need to have it introduced to us and no bearing on whether we already know it. Evidently, it is one thing to be pre-acquainted with anxiety itself, to know it intimately, from out of one's own experience, and quite another to be able to bring it correctly to expression, through acts of predication and in an articulated understanding of what it is. Evidently, our preacquaintance with anxiety itself, from out of ourselves, does not always express itself through correct predications. On the one hand, anxiety itself, as an experience, does not depend at all upon its conceptual presentation, upon the rectitude of our speech and understanding with respect to it. On the other hand, knowing how to name this experience, knowing that we have, each of us, experienced anxiety itself, does not necessitate or guarantee that we are able to speak about it properly. It does not ensure, even, that we know how to do so.

We already know this affect, knowing it simply in that we are affected, even when we would fail to refer to it as an affect and fail to understand it as such. Freud does not demand that we first learn to speak more correctly (or avoid speaking incorrectly), in order then to familiarize ourselves with anxiety itself. On the contrary, he is able to clarify how anxiety itself is to be correctly addressed only on the basis of assuming our prior familiarity with it, only under the given assumption of that given familiarity. Anxiety itself, as an affective condition, does not first have to be interpreted in order to be 
experienced. The experience, including our given familiarity with it, is prior to any such interpretation. No matter how it may be understood or interpreted, whether it is mistakenly called a sensation or grasped (more correctly) as an affective condition, there is in any case no need for its introduction or presentation.

Freud would disabuse us of a likely misconception or misinterpretation regarding anxiety itself, doing so by first using a wrong word to speak about it. He wards off this erroneous expression by performing it, as though it were part of an apotropaic gesture which must first invoke and solicit the very thing it would repel. By first placing anxiety itself within a class to which it does not properly belong (as a sensation), he allows himself to carry out its relocation or reclassification, to reposition or transpose it back into its correct place. He gives himself the opportunity to restore it to its rightful place, to return it to its proper position or topos, by placing it under its true category. An initial, reductive translation of anxiety itself, in which it is taken as a mere sensation, must be supplemented by a revised, secondary translation, whereby anxiety itself comes to be posited (more) correctly, namely, as an affective condition.

Yet the need for this emendation or remediation arises only because we may still find ourselves simplifying and misconstruing anxiety itself. We may mistakenly place it where it does not belong, doing so, however, as those who, being already acquainted with it, also do not need to have it placed before them or proposed to them. The need to position or reposition anxiety itself by means of this corrective measure thus arises in that very place where another need remains suspended or withheld, where this other need comes to be addressed only by way of its foreclosure, under the assumption that there is no need for the presentation (or representation) of anxiety itself. And while Freud says nothing in this passage as to how the presentation or introduction of anxiety itself first becomes unnecessary, other than to tell us that we have already come to know it from out of ourselves - which is, presumably, something every one of us must already know - he does insist upon a certain understanding of anxiety, namely, that it is an affect or an affective state, that it would be expressed or spoken of more correctly as such. 
Why does Freud take the time to say that anxiety refers not to a sensation but to an affective state? Does this distinction have any bearing at all upon our assumed preacquaintance with anxiety itself? The question concerns not only how affects and sensations are to be conceptually differentiated but, more importantly, how this difference comes to be neglected and even covered over in the experience of anxiety. If anxiety, even as it names a most familiar and common experience, allows itself to be misunderstood in this way, what is at stake in this misunderstanding?

Yet with respect to this question, the passage under consideration is of little to no help. Without offering any clarification, Freud simply tells us here that we are all familiar with anxiety in that each of us already knows this affective condition from out of ourselves. We already know anxiety without mediation or introduction insofar as we are ourselves already affectively conditioned in this way. Anxiety as this Affektzustand needs no introduction, in other words, because everyone without exception has already found themselves in it. But nothing is said here about how we are to understand our own way of being actually conditioned by this affect and in what way this affective condition differs from a mere sensation. And even when, two pages later, an attempt is made to clarify the sense in which anxiety is an affect, an undeniable emphasis still falls upon our inability to speak precisely about this experience. Having just told us that we all know without further ado what is meant by "anxiety," Freud now finds it necessary to concede that a certain intractable indeterminacy and ambiguity attaches itself to this word. Nevertheless, he then goes on to declare that "for the most part" anxiety is understood as that subjective condition or state which is brought about by the perception of becoming anxious, and this is what is called an affect: "Zumeist versteht man unter Angst den subjektiven Zustand, in den man durch die Wahrnehmung der 'Angstentwicklung' gerät, und heißt diesen einen Affekt" (FSA 1, 382).

We will have to return to this difficult passage at the end of this paper. For now I only want to note, still in a preliminary way, how a fundamental tension remains unresolved here. We are told in succinct terms what it means to call anxiety an affect: to say that anxiety is an affect is to understand it as a "subjective condition" grounded in a perceptual experience. And, presumably, as such a subjective condition, anxiety names a 
condition or state which defines us as subjects and which conditions us in our very subjectivity, insofar as we find ourselves affected in it and conditioned by it. But what is more important here is that we also experience this condition of our own subjectivity as something which comes over us, as a condition or state we get into or enter into, through a perception. It thus belongs to the experience of anxiety, to its way of coming to affect and condition us, that in this experience we also perceive ourselves becoming anxious. Anxiety does not come to affect us, in other words, except insofar as we also perceive ourselves coming into this affective state. Moreover, we never merely perceive ourselves in this condition or state of being affected without also perceiving ourselves coming into this affective condition or state through our own perceiving of it. According to Freud, then, anxiety is a perception in which anxiety (as a becoming anxious) is perceived and in which we perceive our own becoming affected through this self-perception, that is, by perceiving ourselves becoming anxious. It is a perceptual experience in which one also perceives oneself coming to be affected by this perceptual experience. To say that one finds oneself subjectively conditioned in this way, affected in this perception or selfperception, means only that one is constituted as a subject in a certain self-affection, or auto-affectivity, by also being able to affect oneself through this self-perception. To undergo this perceptual experience is not only to find oneself affected but to find oneself affecting oneself. This is, Freud says, just what it means to call anxiety an affect.

But if the affect of anxiety is grounded in the experience of an actual perception, this experience remains irreducible to the presumed simplicity of every mere sensation or feeling, since, like all perceptions, this affective state comprises a manifold of differentiated but interconnected moments which allow themselves to be interrogated and interpreted by the perceiving subject. Every perception opens up within a horizon of merely possible perceptions. Precisely as a perception in which we perceive our own being affected, the condition of anxiety sets itself apart from the immediacy of a sensation in the classical sense. It distinguishes itself not merely by virtue of what it discloses but, more fundamentally, by the complex manner in which that disclosure imposes itself upon us. As a perceptual experience anxiety does not merely present us with a sense datum and cannot be defined by any singular moment. And, as we still have to see, Freud 
understands this experience as a protracted event which takes time and which unfolds in time. On Freud's own terms, then, anxiety is something more than a mere condition in which find ourselves passively affected - that is, conditioned by the affect itself as a sheer facticity - since we also find ourselves involved in this experience as a perceptual event and since this event is temporalized through our participation in it and by anticipatory moments which claim us without allowing themselves to be decided in advance. Anxiety is a perception and not a mere sensation in that through our own acts we are made aware of concerns as they affect us, by involving us directly in them without recourse. We thus find ourselves claimed by this perceptual affect through our own perceptual activity. We are conditioned and constituted in its disclosure precisely as it would expose us to the actuality of our own situation and as that actuality solicits our engagement and calls us to respond to it.

Still, if the distinction between an affective state and a sensation depends upon the perceptual character of the affect, we might then want to consider more carefully how anxiety is to count as a perception. Ordinarily, we speak of our perceptions by referring to what is perceived through them. We relate to the world visually, for example, because of what becomes visible for us through sight. We see things and are aware of our seeing only through the things we see. But an anxious state, strictly speaking, does not refer to anything perceived in this sense, inasmuch as anxiety is not an experience of anything other than anxiety itself. The only thing revealed to us by anxiety is our own anxiety, our own becoming anxious. ${ }^{5}$ In one sense, it cannot even be said that we are affected by

\footnotetext{
5 Freud, of course, does not claim that anxiety lacks a content or that it is not directed toward anything. He does not claim, in the manner of Kierkegaard, Heidegger or Tillich, that anxiety differs from fear, in that fear is always fear of something, whereas anxiety exposes us to non-being and nothingness. On the contrary, Freud assumes that there must be something there before which one becomes anxious, something present and actual by which one makes oneself anxious: "Wir werden doch zunächst die Erwartung festhalten wollen: wo die Angst ist, mu $\beta$ auch etwas vorhanden sein, vor dem man sich ängstigt" (FSA I, 387). Not only is it assumed that anxiety must be correlated to some intentional content, or some object, but a solution to the problem of anxiety, as Freud understands it, entails the discovery and determination of this content. In the New Introductory Lectures (1933), in the supplemental lecture on anxiety, we are told that the original pyschoanalytic explanation of anxiety (as the transformation of frustrated libidinal energy) has to be understood as it claims to account for what is feared in neurotic anxiety. Thus, according to this earlier, but now superseded explanation, what is feared in anxiety is one's own libido. In Freud's words, the earlier explanation also concerned "wovor man sich bei neurotischer Angst fürchtet" (FSA I, 520). And, later in that same text from 1933, at the very end of the new lecture on anxiety, in the course of presenting and developing a new explanation of anxiety (as it would supplant the original account of repressed libidinal energy), Freud returns again to the question concerning the content of anxiety. If anxiety is now to be understood as a signal which anticipates the return of a dangerous situation, then there must be an original experience which made this signaling possible and to which it refers - if, that is, it is to be a signal announcing the return of something. And this original experience, as a traumatic event, is now
} 
anxiety, insofar as anxiety itself names not what affects us but nothing other than the affect itself as a way of being affected. If this affective state consists in a perception, it is a quite peculiar perception in which nothing is perceived other than the perceiving perception itself which perceives its own perceiving as a self-perceptivity. Moreover, we also find Freud himself distinguishing anxiety from perception. He tells us, for example, not that anxiety is a perception but that it is instead something precipated by a perception, a reaction to a perception. Real anxiety, he says, is "a reaction to the perception of an external danger" (FSA 1, 381). And, to make matters still more complicated, we also find him at times continuing to refer to anxiety as a sensation, especially when he wants to emphasize the merely "subjective" character of this experience. 6 The difference between sensation and affect frequently comes to be blurred, if not entirely erased. And, on

said to be what is feared in anxiety, as the object of anxiety: "das Gefürchtete, der Gegenstand der Angst, is jedesmal das Auftreten eines traumatischen Moments, der nicht der Norm des Lustprinzips erledigt werden kann” (FSA I, 528). Even so, despite this assumption or insistence that anxiety must correlate to something experienced or perceived (for example, a situation of danger or a traumatic event), anxiety as an experience also tends to conceal and distort what it is actually concerned with. This is especially evident in cases of neurotic anxiety. Thus, strictly speaking, anxiety refers first of all to the subjective state or condition rather than to the object which provokes that state. See, for example, at FSA I, 382, where Freud makes this very point even as he also insists upon avoiding the question as to whether or how anxiety, fear and fright (Schreck) might have different senses. Finally, near the conclusion of the important text, Hemmung, Symptom und Angst (1925), in a remarkable passage, a certain stress is placed upon the anticipatory character of anxiety, such that it always is, Freud says, an anxiety before something, an expectancy. But, just for this reason, he continues, the content of anxiety is deprived of objectivity and determinacy, becoming a "fear" only once it is able to attach itself to some object. We will see that it is for this very reason that even so-called "real" anxiety remains haunted by its own essential irreality. This text from 1925 also offers a concise account of Freud's understanding of the problem of anxiety at the time, precisely as it bears upon the relation between real and neurotic anxiety. I cite the full passage in the original German and then translated, but unfortunately must forego any further interpretation. I will, however, return to the importance of "expectation" shortly, when I take up Freud's account of Angstbereitschaft in the Introductory Lectures. Here is the passage: "Der Angstaffekt zeigt einige Züge, deren Untersuchung weitere Aufklärung verspricht. Die Angst hat eine unverkennbare Beziehung zur Erwartung; sie ist Angst vor etwas. Es haftet ihr ein Charakter von Unbestimmtheit und Objektlosigkeit an; der korrekte Sprachgebrauch ändert selbst ihren Namen, wenn sie ein Objekt gefunden hat, und ersetzt ihn dann durch Furcht. Die Angst hat ferner außer ihrer Beziehung zur Gefahr eine andere zur Neurose, um deren Aufklärung wir uns seit langem bemühen. Es entsteht die Frage, warum nicht alle Angstreaktionen neurotisch sind, warum wir so viele als normal anerkennen; endlich verlangt der Unterscheid von Realangst und neurotischer Angst nach gründlicher Würdigung" (FSA VI, 302). "The affect of anxiety exhibits features the study of which promises a greater elucidation of the subject. Anxiety has an unmistakable relation to expectation: it is anxiety before something. It has a quality of indeterminacy and objectlessness. In precise speech we change the name and use the word fear instead of anxiety when it has found an object. Moreover, in addition to its relation to danger, anxiety has a relation to neurosis which we have been trying to explain for some time. The question arises as to why there are anxiety-reactions which are not neurotic, why we regard so many as normal; the distinction between real and neurotic anxiety ultimately requires a fundamental assessment." ${ }^{6}$ The perceptual character of the affect is repeated by Freud in his 1933 summary of the lecture. See FSA I, 517. Freud also confirms that the account of anxiety presented in the earlier lecture hinges on the understanding of what an affective condition is. When he concludes his summary of the earlier lecture, by way of referring to its inconguities and apparent incoherence, he makes clear that the lecture considers anxiety in this respect: "Die Angst ist als Affektzustand..." (FSA I, 520). 
occasion, Freud even stresses our total ignorance in this domain. We call anxiety an affect without knowing what an affect is. ${ }^{7}$

We see, then, that Freud's insistence that anxiety is an affect or an affective state - that it is an experience in which we find ourselves affected - does not merely concern a possible rectification of our understanding but, as it turns out, indicates the obscure manner in which anxiety comes to be given for us and is already given for us: it is given for us, for each of us, but only insofar as we are given to ourselves in and as this affect. But this insistence also indicates why the presentation of anxiety itself remains unnecessary, how the need for that presentation is withheld, becomes impossible. The (auto-)affective character of anxiety would be intrinsically linked to the disavowal of the need to present it, since we no more need to be introduced to this anxiety than we can be made aware of ourselves as both affected and self-affecting subjects. ${ }^{8}$ And while there is nothing here to suggest that we might need to be reminded of the anxiety we already know, how would we ever be returned to ourselves from such a self-forgetting, if not by finding ourselves once again anxious? But if we come to know anxiety only as we find ourselves affected, we also cannot know it at all except by first knowing ourselves in the affect, knowing how we are anxious, as we find ourselves delivered to our own anxiety, from out of ourselves.

粠将

Not only does Freud introduce anxiety itself without needing to introduce it, he introduces it only then to withhold that needless introduction. And, on the occasion of this strange and needless introduction, the opportunity arises, so it seems, to reform our understanding. Anxiety itself is presented as what need not be presented and just this

\footnotetext{
7 Consider the telling remark at the beginning of the eighth chapter of Hemmung, Symptom und Angst (1926): "Die Angst ist also in erster Line etwas Empfundenes. Wir heißen sie einen Affektzustand, obwohl wir auch nicht wissen, was ein Affekt ist" (FSA VI, 273).

${ }^{8}$ In the third part of das Unbewußte we are told, remarkably, that an affect is never unconscious, although a distinction is also drawn here between a given affective experience (as a perception) and our understanding of it. "It may come to pass that an affective stirring[...] is perceived but misrecognized (or distorted, verkannt)" (FSA III, 136). In other words, it is possible for the representation or Vorstellung of an affect to be repressed, such that the affect comes to be connected to another representation, but it is not possible for the affect itself to be repressed or distorted. In other words, as an affect or affective condition, anxiety is tied directly to our consciousness of ourselves. See also the passage in Hemmung, Symptom und Angst, in which Freud emphasizes that it is precisely as an affective condition that anxiety is directed connected to the experience the ego or I has of itself. "Die Angst ist ein Affektzustand, der natürlich nur vom Ich verspürt werden kann" (FSA VI, 280).
} 
(non-)presentation appears to provide the opportune moment for the rectification of a slight misunderstanding. Freud mentions in passing that anxiety more correctly names an affective condition, as though he were only pointing out a trivial case of mistaken identity. Hardly any emphasis at all is placed upon this passing remark which, being offered as an aside, receives no elaboration. There is nothing at all to indicate how an affect differs from a sensation or why it would be important to mark such a difference. The comment, inserted parenthetically, appears at first to be only tangentially related to the strange introduction of anxiety itself.

But, just as Freud only appears to introduce anxiety itself - by introducing it without needing to introduce it and only not to introduce it - he also only appears to clarify our understanding of anxiety itself: he makes clear only that we do not understand. While it appears as though Freud would needlessly clarify what is already clear, he also leaves unclear how we are to understand this very clarification. The introduction of anxiety itself, in which it is not actually introduced, provides the opportune moment for a further clarification in which nothing is actually clarified.

Freud's remark that anxiety itself is more correctly addressed as an affect thus proves to belong to the strange and perplexing presentation of anxiety itself. That presentation is itself introduced as something unneeded because what it would present (anxiety itself) is presumed to be obvious, entirely clear to everyone. Yet this superlative and exceedingly apparent clarity also harbors its own stubborn opacity. There is no need for the presentation of what does not allow itself to be presented, no need to question that which refuses to be communicated, which remains unpresented because it first of all cannot be presented.

Yet this strange presentation - performed under its erasure - also anticipates a certain problematizing of anxiety. The double gesture which both introduces and withholds anxiety itself, in which it is also affirmed as an affective state, does not serve as a mere corrective so much as it prepares the way for the ensuing discussion in which anxiety comes to be presented or posed as a problem, namely, as that very problem anxiety itself presents or poses when it is considered not as a sensation or a mere feeling but as an affect. As an affect, anxiety refers not only to a feeling but to one way in which 
we find ourselves, by relating to ourselves and appearing to ourselves in our being affected. Strictly speaking, however, this experience of oneself does not have to present an actual problem. It becomes a problem for us only once we find ourselves needing to explain it, and not without our assuming that we are actually able to explain it, that is, from some assumed understanding of what such an explanation demands and how these demands are to be satisfied. While there is of course no guarantee that a problem will be solved, the very posing of a problem would become incomprehensible if it were not already at least the promise of its solution, that is, as a possibility.

Freud's problematizing of our basic need to make sense of ourselves in our anxiety, to respond for ourselves being delivered over to this anxiety, claimed by it, thus amounts to the demand that we explain to ourselves how we have come to be affected in this way. More precisely, anxiety posed as a problem imposes the demand that we account for ourselves by explaining how the affect has come to be within us, by accounting for its cause - whether this means taking it to be the distorted expression of a frustrated libido (wine turned to vinegar) or, even, the signal announcing danger and the possible return of trauma and helplessness. 9 The problematizing of anxiety is then the problematizing of our self-understanding; it is a self-problematization through which a self-understanding

9 It is no secret that, during his prolonged preoccupation with the problem of anxiety, Freud's understanding not only of this problem as such but of its possible solution undergoes a number of decisive shifts and transformations. (So, for example, the oft-cited passage at FSA I, 528, at the end of the New Introductory Lecture on anxiety, definitively abandons the claim that anxiety is a distorted expression of the libido.) By no means, however, can it be said that these transformative developments lead to a resolution of the problem. On the contrary, Freud himself continues to insist, even at the end of his carreer - in the New Introductory Lectures (1933) - that the problem remains unresolved and that even his most recent attempts at a solution are to be regarded as provisional and inconclusive: "hier, wo wir von der Angst handeln, sehen Sie alles in Fluß und Wandlung begriffen" (FSA I, 527). Scholars are quick to point out how the account of anxiety put forward in the text we are examining (namely, in the Introductory Lectures) should be read cum grano salis, since it remains a transitional and experimental mixture of seemingly incompatible and undeveloped viewpoints. It is also the case that Freud himself makes this very point in his own summary of the earlier lecture. "...one senses that something is missing here that would bring these fragments together into a unity" (FSA I, 520). (And see also FSA VI, 273: "Bisher haben wir nichts erreicht als Widersprüche, zwischen denen ohne Vorurteil keine Wahl möglich war.") But, arguably, such self-criticism is to be heard not so much as it would trumpet the superiority of the later position - that is, over and against the supposed failings of the earlier, more incoherent view - as much as it is an exhortation to continue to examine our assumed understanding of anxiety critically. It certainly exceeds the scope of this paper to retrace in any detail the actual development of Freud's conception of anxiety. I will insist, however, that even as this conception shifts and becomes more nuanced, what is never once put into question is the problematizing method which seeks, by reflecting upon the experience of anxiety retrospectively, to find a causal explanation for that experience. The fundamental premise operative here is that the problem of anxiety presents a problem of knowledge and understanding. Thus, even as Freud claims, for example, that repression results from anxiety and not the other way around (FSA I, 521, 524) or that neurotic anxiety proves to be an experience of real anxiety (FSA I, 521) or that the ego is exclusive site of anxiety (die Angststätte), what remains constant is the search for a causal ground which must not only proceed from an assumed affective experience (anxiety itself) but, even, deny the primacy of this experience, that is, of what it must first assume as originally given. 
would be explained. Yet what informs any such explanatory attempt is never only the presumed need to construct après coup an aetiological explanation of oneself but first of all the self-aware experience (the affective state) which first calls for this explanation: what we would account for, by means of analysis, is nothing other than the way we find ourselves already affected. Such an explanation, if it were possible, would not only accomplish a self-explanation, it would have to transform the affective self-understanding from which it begins. It would have to bear upon the experience of anxiety itself. An actual solution to the problem of anxiety would not only have to solve that problem but, by explaining anxiety itself, would have to render that affective condition plain to itself from out of its ground, that is, by actually altering the affect, by affecting it as a self-perception.

There is, then, no possible approach to the problem of anxiety which does not involve us from the beginning. Not only do we always proceed from the experience of the affect as such, but the problematizing of that experience remains only one way of responding to it, only one way of accounting for ourselves in giving that response. The privileging of anxiety as a problem thus always runs the risk of covering over the experience it would explain. Even so, Freud himself will insist that, if our experiences defy problematization, this does not reveal the inadequacy of our understanding as much as it demands a greater fidelity to those experiences themselves. So, for example, it is especially noteworthy that when he claims that his unique understanding of the affects must be regarded as one of his distinctive accomplishments, since it has "grown upon the soil of psychoanalysis," he also concedes that this amounts only to a "first attempt directed at this obscure realm," adding that "we are also not fixed upon the certainty of our knowledge of the affects" (FSA I, 383).

次次

Are we not able to respond for our own anxiety, not merely for the problem of anxiety but for anxiety itself? Do we not have to respond for it? Does this anxiety not call us to account for it, to account for it as anxiety itself? Are we not ourselves delivered over to this affect as we are called to account, being ourselves already accountable not only for the account we still have to give and can fail to give, but no less to what we would account for in that still ungiven account, by giving it or by failing to give it? 
Yet this call to account for anxiety, as a summons or solicitation, demanding our response, would also call to us from out of ourselves, by calling us to ourselves and even to our anxiety. It would call us to being ourselves as this anxiety. It would awaken or provoke that very anxiety we would still become or properly are in our being able to respond to this call. Being called in this way, both to ourselves and to our own anxiety, we would be made still more anxious in the very call which calls us to account not only for this anxiety but also for this being called, to account for anxiety as it calls us to account for it and for ourselves as we find ourselves called. Anxiety would thus call us to an originary responsibility for ourselves precisely because this self-responsibility is already its own anxiety.

But if what calls us to account for (our) anxiety is nothing other than anxiety itself, as we find ourselves affected, then to be called to account for this experience from within it and from out of ourselves, by having to account for the experience itself as it claims us or affects us, is not only to be called to account for an experience, nor is it even only to be called to account for how any experience whatsoever can demand such an account. Rather, in finding ourselves at this limit, having to respond to this solicitation, we would be called to account for an experience as it calls us to account for our being both able and unable to account for this experience of ourselves. Anxiety is then not only a being responsible for oneself but also the irrecusable irresponsibility which inheres in that proper being, by claiming us and threatening us the moment we find ourselves unable in our ability to respond to it, to what, by calling to us, also calls us into question. Responsibility is awakened to its own anxiety not only in its ability to respond but in the vertiginous contingency of that (in-)ability which can be able only as it also remains able to be unable. ${ }^{10}$ Anxiety would be this dizziness which awakens not only to its own inability but to its being able to respond for that inability, for its own having to be responsible in its irresponsibility. Responsibility first of all can awaken to its own anxiety because anxiety is itself an original awakening to responsibility.

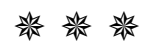

10 This, I take it, is what is at stake in what Georgio Agamben calls "impotentiality." 
As an affect or affective state, anxiety names how we are given to ourselves, one way we can be given to and for ourselves. Not the problem of anxiety but anxiety itself, as this affect, names this experience of ourselves. It names our self-awareness in that experience. The affect thus refers both to the way we are affected and to the way we find ourselves affected in this way. The assumed givenness of this experience so little results from the posing of the problem of anxiety that instead it is nothing other than this experience which first establishes the place from which this problem can be posed.

Freud's insistence upon the affective character of anxiety, that it must be considered as such a condition or state, in which we come to ourselves or find ourselves affected in a certain way - his insistence, namely, that anxiety itself is precisely the conscious awareness, or the perceptual consciousness, which takes itself to be so affected - thus serves as more than a remedial measure. It not only provides an antidote to a likely simplification or presumed misunderstanding with regard to anxiety itself but is inserted here strategically, by prefiguring and setting the stage for the presentation of anxiety as a problem, of that very problem anxiety itself presents, which is the primary task of this lecture and which, strictly speaking, must be rigorously distinguished from the (unposed) question of anxiety itself and its (unneeded) presentation.

According to Freud himself, it is hardly possible to overstate the decisive importance of this problem. The problem posed by anxiety, as the problem of anxiety that is, as das Problem der Angst or das Angstproblem - is not just any problem, not just one problem among others. Anxiety sets itself apart as a problem; it distinguishes itself in the way that its problem proves to be related to a host of other problems. Like the center of a web or a net, this problem marks a nexus, an intersection or a crossing. It names that "nodal point" or knotted punctuation (Knotenpunkt) at which the most important and varied problems of the human psyche are entwined and ensnarled, entangled. One could say that the crux of the matter is always anxiety, since the solution to its riddling problem would provide the key to unlocking a whole series of interconnected and interlocking problems. This problem either results from these other problems as a whole or is the source from which they all spring. As a point of convergence, it also marks a point of 
differentiation and divergence. Almost immediately after the passage in which anxiety itself is introduced, Freud declares:

[...] what remains constant is that the anxiety-problem is a nodal point at which the most divergent and important questions converge, a riddle whose solution would have to shed light on our entire ensouled life. I will not maintain that I am able to give you this full solution [...] (...es steht fest, daß das Angstproblem ein Knotenpunkt ist, an welchem die verschiedensten und wichtigsten Fragen zusammentreffen, ein Rätsel, dessen Lösung eine Fülle von Licht über unser ganzes Seelenleben ergeißen müßte. Ich werde nicht behaupten, daß ich Ihnen diese volle Lösung geben kann...) (FSA 1, 380)

It thus becomes evident that while there is, on the one hand, both the problem of anxiety and the problem of how to present this problem - the problem of where, when and how the problem of anxiety is to be introduced and presented, namely, as that very problem anxiety itself presents - there is also, on the other hand, anxiety itself, anxiety per se, which in no way needs to be presented, set forth or proposed. And whereas finding a solution to the problem of anxiety depends entirely upon how we take upon ourselves the task of posing that problem (and varies as a possibility according to whether and how the problem is understood and actually posed by us), anxiety itself, by preceding every possible presentation or proposing of it, cannot promise or demand any solutions, no more than it ever poses a problem.

It is clear from the very beginning of this lecture, from the way in which it begins, that it is concerned not merely with anxiety but with the problem of anxiety, with anxiety not as itself but as a problem. Freud's concern is anxiety but only as it becomes a problem or comes to present a problem, by presenting itself as the problem it presents. Yet it is also the case that it belongs to the possible appearing or presenting of this problem, to the conditions of its very problematicity, that we find ourselves participating in its problematization or its becoming problematic, that it necessarily involves us as accomplices in the very problem of its own posing. Anxiety cannot be posed as a problem 
at all without our active engagement with it, except as it solicits our interpretive response, in response to its appearance.

Yet this very difference, between anxiety itself and the problem it comes to pose, remains as precarious as it is necessary. On the one hand, it must be established prior to the development of the problem, and prior to every possible conception of anxiety. And yet, on the other hand, the problematizing of anxiety is not only premised upon this difference, since that operation by which anxiety is posed as a problem must also threaten to distort the anxiety it renders problematic.

The need to present or pose the problem of anxiety, as the posing of that very problem anxiety itself poses, thus asserts itself within a space held open by a certain lack of need, in that opening where there is in the first place no need to present anxiety itself, where every need for such a presentation is withheld, precluded in advance. The place for the presenting or placing of this problem, the very possibility of its posing and being posed, is held open by the assumed foreclosure of the need to present or introduce anxiety itself, is granted by the withdrawal of such a need from every possible appearance, presentation or problematization. Freud's entire discussion of anxiety, in which its problematic appearance is elaborated and addressed, is thus allowed for by the wholly unproblematic and unpresented appearance of anxiety itself. It is made possible by an appearing which retreats or recedes from its possible presentation, which appears only by first preceding every possible thematizing and problematizing of that appearing. Anxiety first appears, always has appeared as itself, as anxiety itself, prior to every possible problematizing of its appearing. And, moreover, it must appear in this way, if the problem of anxiety is to be raised and posed as a problem at all.

At the very beginning of the lecture, just before the passage we have been examining, Freud introduces the need to take up this problem. He accounts for his way of both posing and not posing it, and, above all, for the apparent delay in his getting around to posing it. Not only does he address the need to address this problem, that is, by posing it, by bringing it to expression; he also addresses the need to address this need. Freud thus introduces and addresses the problem of how to bring this problem up and how to bring it into focus, the problem of how to pose it so as to allow it to pose itself. 
This problem - the problem, namely, of how to introduce and pose the problem is introduced by Freud as he refers his audience back to the preceding lecture, in an effort to acknowledge its deficiencies and shortcomings. Freud takes the opportunity here to imagine how frustrated his audience must have been by that lecture, in which common neuroses or nervous disorders (die gemeine Nervösität) were discussed without any apparent regard for the undeniably important role played by anxiety in such cases. $\mathrm{He}$ readily concedes that nothing could have been more puzzling than this omission, that anxiety was not taken up where most of all it deserves consideration, since "most of those who suffer from nervous disorders complain about it [anxiety], which they themselves describe as the most terrible of afflictions and which, by achieving in them a most remarkable intensity, can give rise to the most outlandish eccentricities." 11

But, Freud insists, his intention was never to disregard or cut short any such concern with anxiety. So little does he want to curtail this concern that, on the contrary, he now confesses that he has for some time been working toward this moment, anticipating it, by intentionally deferring his presentation of the problem of anxiety, by holding it in reserve so as to postpone its posing, while also planning and preparing for it, taking measures to make it possible, all for the sake of enhancing its effect, in order to augment its efficacy. The apparent disregard for anxiety in the foregoing discussions, rather than indicating any kind of neglect on Freud's part, was instead already focused upon attending not only to anxiety but to the problem it poses, was already intent upon the explicit and clear posing of that problem. Freud's apparent failure to address anxiety has now set the stage for that problem, for the clear posing of that problem. By withholding this problem, in other words, a place has been reserved in which it may now emerge in its own right and receive its due consideration.

The task now is to bring this problem sharply into focus (as it pertains to those suffering from nervous conditions), that is, to bring it to the fore with a dedicated precision and rigor, to address it thematically, to raise it as a topic and to discuss it thoroughly in its proper place - that is, with respect to its problematicity. A stark contrast

11 "[...] über die doch die meisten Nervösen klagen, die sie selbst als ihr schrecklichstes Leiden bezeichnen und die wirklich die großartigste Intensität bein ihnen erreichen und die tollsten Maßnahmen zur Folge haben kann." (FSA 1, 380). 
between two modes of setting or posing, corresponding to a need and to a lack of need respectively, thus becomes evident: it is a matter, on the one hand, of focusing clearly upon the problem of anxiety so as to pose it, to bring it into relief thematically, to dial it in or dial in on it, to insert it into the discussion through its articulation (das Problem der Angst [...] einzustellen) and, on the other hand, of not having to present or introduce anxiety itself (die Angst selbt [...] nicht vorzustellen).

Freud has been making plans, has been assuming things ahead of time; he has been taking in advance so as to give to himself what he takes: ich habe mir vorgenommen. And without this plan or anticipatory intention, by which the problem of anxiety is first situated within Freud's presentation, that problem would never arise at all, would never present itself as a problem. Whereas the intention all along has been to present this problem as clearly as possible, to focus upon it with extraordinary precision and to bring it into view for you, to discuss it thoroughly before you (to situate or position it explicitly in front of you, to lead you through it, by unfurling or unfolding it, so as to place it before you, es ausführlich vor Ihnen zu erörtern), there is, however, no need to present anxiety itself, no need to present what cannot be presented, since it has always already presented itself to us, from out of ourselves.

We thus see that the lecture must begin by marking this difference as such, between anxiety and its problem, precisely as this difference aligns with two corresponding modes of placing or setting, two differing modulations of Stellen, and, moreover, as each of these two modes expresses or addresses a distinct need, one of which asserts itself urgently, as the focal or foreground need governing Freud's entire lecture, while that other need remains suspended, is held in abeyance and referred to only by way of its absence, only with respect to something altogether unneeded or needless.

For the sake of clarity - albeit at the risk of needlessly belaboring the point and rendering my own presentation redundant, pointless - permit me once more to cite the passage under consideration, this time with the last lines of the preceding paragraph included:

On the contrary, my plan has been to bring the problem of neurotic anxiety into especially keen focus and to discuss it for you (before you) 
thoroughly. (Ich habe mir im Gegenteil vorgenommen, das Problem der Angst bei den Nervösen besonders sharf einzustellen und es ausführlich vor Ihnen zu erörtern.)

Yet there is no need for me to introduce anxiety itself to you; every one of us has at some time on our own become acquainted with this sensation or, to speak more correctly, this affective condition. (Die Angst selbst brauche ich Ihnen ja nicht vorzustellen; jeder von uns hat diese Empfindung oder, richtiger gesagt, diesen Affektzustand irgend einmal aus eigenem kennengelernt.) (FSA 1, 380)

We must not lose sight of what is most decisive here: although a certain emphasis is placed conspicuously upon the difference between the problem of anxiety and anxiety itself, more decisive still is the manner in which this pronounced difference establishes and sustains itself. This difference does not refer only to what is differentiated, as though it were to result only from two unrelated terms which, without coinciding, also remain indifferent to each other. As a difference which is established by relating two appearances, precisely with respect to their way of differing from each other, the difference at issue here also relates two different ways of appearing. It refers to the appearing of anxiety as a problem, which, in its way of appearing, differs from its appearing as itself, that is, from its way of appearing not as a problem but as itself. What is decisive, then, is that the difference expresses the modes or modalities in which the two appearances come to appearance by appearing differently, according to that way of appearing which is proper to each, such that each comes to differentiate itself from the other by appearing differently, by appearing in a different manner. These two different ways of appearing amount to a difference belonging to anxiety, to its way of appearing and presenting itself, by differing from itself. Anxiety appears as itself by also differing from itself, by appearing in its self-differing.

The appearance of anxiety as a problem, its way of showing itself, is bound up with our need to present it, as this need imposes upon us the task of posing that problem. Anxiety itself, however, appears without needing to be presented. It appears by presenting itself, by having already presented itself without need, by appearing needlessly, without 
having to be presented but also without being presented. It does not need to be presented because it never is presented, cannot be presented. Anxiety itself cannot need any presentation, since it has always already presented itself to us, to each of us from out of ourselves, before it can be presented by us, before we would ever be able to bring it to appearance by presenting it to ourselves and to each other. It appears as itself, then, only if it also withdraws from its own appearance, by disappearing in that appearance and appearing only as this disappearing, which, by appearing, is already on its way to becoming a problem. By having always already appeared, being apparent to everyone, it is as though anxiety itself can never actually appear. Already apparent everywhere, it also appears nowhere, remaining inapparent.

Anxiety itself thus names the given but indeterminate horizon from which anxiety is allowed to come to appearance as a problem, and only if that problem appears or presents itself enveloped or environed by that prior horizon. The possible clarification of the problem, which is nothing less than the problematizing of anxiety, is grounded in and established against an obscure background, the given but unquestioned appearance of anxiety itself, its way of being given as an experience. The problem of anxiety, its presentation or posing, can be brought to the fore and into focus only insofar as anxiety itself continues to provide this background. It is not merely the open space within which the problem is posed, which first grants us passage into the problem, but the problem is presented and brought to appearance only as this background or open space withdraws from appearance. Only by remaining needless does the given appearance of anxiety itself allow for the posing of anxiety as a problem, for what becomes necessary or needed with this problem, precisely by preceding every possible presentation, every possible need.12

\footnotetext{
${ }^{12}$ It is worth noting that the later lecture on anxiety, presented in the New Introductory Lectures (1933), begins by marking this same difference. On the one hand, Freud stresses the superlative difficulty of the task at hand, that nothing of what he is about to present provides a definitive solution to the problems surrounding anxiety. On the other hand, these problems and the tremendous difficulty they present are grounded in an assumed experiential givenness. It is precisely "the most frequent and most familiar phenomena which put this riddle to us (es sind gerade die häufigsten und vertrautesten Phänomene, die uns jene Rätsel aufgeben)." Moreover, this very difference between an unproblematic but no less riddling experiential givenness and the need arising from it, naming, its need to be supplemented by a certain problematizing order, is articulated here as the need for the right conceptions or "Auffassungen." Freud places a special emphasis upon his choice of words ("In bestimmter Absicht spreche ich hier von Auffassungen."), with the clarification: "[...] es handelt sich wirklich um Auffassungen, $d$. h. darum, die richtigen abstrakten Vorstellungen einzuführen, deren Anwendung auf den Rohstoff der Beobachtung Ordnung und Durchsichtigkeit in ihm entstehen läßt” (FSA I, 517).
} 
We have, each of us, become familiar with anxiety itself, with this affective state. We have learned it, learned to know it, by knowing it as our own and from out of ourselves, in our own kinship with it and relation to it. We know it in this experiential familiarity or kinship, as it belongs originally to our own ken and kin. "Jeder von uns hat [...] diesen Affektzustand irgend einmal aus eigenem kennengelernt." We do not merely know it as this kinship or familiar relation, posited as such in our thetic consciousness, but this kinship is itself our way of being acquainted with it, with anxiety as itself. Anxiety itself is this intrinsic gnosis which precedes every episteme or Wissen, every interpretation which would return to it and reflect upon it, which would seek to address it or account for it. We feel our anxiety and are affected by it before we form any ideas or representations of it.

It is hardly inconsequential that anxiety itself is introduced as an affective state. As such it names one way in which we may find ourselves, by which we would be present to ourselves. Freud tells us that anxiety itself is this affect, is itself the experience or the state in which we find ourselves immediately affected in a certain way. He does not say that we come to know anxiety through this affect or by means of it. The affect does not designate a mere representation; it is not the means by which we would intend the reality of our anxiety. We do not merely conclude, by means of an apophantic judgment, that this being affected must be what everyone calls anxiety. Being affected is already this knowing awareness, is itself the conscious state or condition in which we "know" anxiety. We know anxiety, then, not by thinking of it but by being anxious. And we are anxious only insofar as we ourselves are this anxiety, by knowing ourselves in it, by being conscious of ourselves through this way of being affected. The affect does not convey or transmit what anxiety originally is, or represent it to us, no more than it is able to reveal what it is as itself - namely, this very affect - except by actually affecting us. Anxiety itself is first revealed to us only as we find ourselves affected. We know it, first come to know it, in the actual experience of being affected, not by reflecting upon that experience.

And yet, it is also worth noting that by hypostatizing this pre-conceptual, prethematic experience or given acquaintance, as the experiential source which remains 
anterior to its possible interpretation and which, as this source, must also be assumed prior to any such interpretation, by both preceding and grounding its articulation (by grounding what is called, at least since Kierkegaard, "the concept of anxiety"), Freud has no interest at all in addressing us as individuals, as those who would be able to assume responsibility for this original experience, who would already be responsible by having to account for ourselves in this experience and who would thus be responsible for anxiety itself as this experience. Freud is not speaking here to anyone in the singular, except as he also speaks to everyone collectively, anonymously, by assuring all of us that everyone every single one of us - already knows anxiety itself, that we each individually and as a whole know it as the same thing and in the same way, having learned about it from out of what is properly or authentically our own, aus eigenem kennengelernt. Each of us, by ourselves - that is, without consulting or referring to anyone else, but also without ever having to decide anything on our own, solely for ourselves or by ourselves - has already encountered or experienced this common, generic anxiety, which is called anxiety itself.

Like a secret which everyone knows but no one tells, anxiety itself thus remains incommunicable. It cannot be shared, even though there is nothing more common. Having it in common, we share it, but without ever being able to share it with each other, without ever needing to share it, without needing it to be communicated by anyone or shared with anyone. And, while it is clear that anxiety itself - as this generic, anonymous property, which is also proper to each of us, to everyone from out of themselves - remains irreducible to a mere disorder or pathological condition, neither does it amount to anything as robust and demanding as the individuated and individuating ontological anxiety which concerned both Kierkegaard and Heidegger.

By referring to our given familiarity with anxiety itself, by taking that familiarity for granted, Freud thus works into his presentation what would be hardly more than a passing remark, as though he means only to state and affirm something quite obvious, to acknowledge as an aside, and without this acknowledgement being needed, what he assumes everyone is already aware of and what he assumes everyone also assumes they are already aware of. Not only does he take the time here to bring up anxiety itself in this seemingly innocuous manner, doing so only to say that bringing it up is, in fact, a waste 
of time, but, by the time he gets around to saying this, there is evidently nothing more to be said about anxiety itself, already no more time for it. He brings it up, telling us how we ought to rightly consider it or represent it, namely, as an affective condition; what is decisive, however, is that he does not (have to) place it before us or make it available to us, does not (have to) first describe it to us, since no one needs to have it imagined for them as a mere possibility, represented as a mere thought or set down as a mere proposition.

There is no need to dwell on this fact, no need to repeat, belabor or elaborate what everybody knows or assumes they know, namely, that we are, each and every one of us, already acquainted with anxiety itself, delivered over to this experience or this condition, already affected and claimed by this pathos, exposed to it. In this exceptional passage, at the very moment he comes closest to confronting the question of anxiety itself, perhaps for the first and only time, he is already moving on, never to return, leaving anxiety itself to itself.

What is asserted or assumed here is not only this given familiarity or prior acquaintance, but, evidently, that we are all undeniably aware of this affect and our familiarity with it, conscious of ourselves in it, that is, not unconscious of having already become acquainted on our own with our own anxiety, as anxiety itself, both as our own and also as this "anxiety itself." The claim here, in other words, is not only that there is no need to inquire into how anxiety comes to show itself as itself, to each of us and to all of us (given that we have already come to know it on our own, not from someone else but secretly, from out of ourselves), but also that there is no need to justify or to explain this very claim, no need to account for what is being claimed and how it rightfully can be claimed.

Not only does everyone already know anxiety itself (on their own), everyone knows both that they know it and also that everyone else knows it; we all know that we all know it. Not only are we no strangers to anxiety but we also already know (or at least assume) that no one is a stranger to it, that no one can be a stranger to it. There is, then, no need to introduce or acquaint ourselves with anxiety itself, by asking whether and how someone might know it, or by what right someone may claim to know it, because we 
already know that everyone already knows it and we all know that we know this, namely, that we all know it, that everyone already knows it. We both know it and know that we know it. What we do not know, not yet at least, is how we all know this; we are simply told here, without explanation or clarification, that at some point we somehow all came to know it all on our own, from out of what is properly our own.

No distinction is drawn here between a merely latent awareness, as a pretheoretical or pre-thematic acquaintance (or fore-understanding), and a more developed, second-order knowing, which, by doubling back and reflecting upon itself, would distinguish itself by coming to know that it knows and even be able to account for how it knows that it knows. And Freud says nothing about how we have come to know that we know what we already know. Knowing anxiety itself, on our own or by ourselves, it is enough to know it, enough to affirm and agree that we all do know it. And, while each of us knows it on our own, privately, without anyone having to tell us about it, we also know that we all know it together. What we first learned privately, on our own, is also what we all know or assume we know in common, namely, this shared knowledge of anxiety itself.

Freud appeals dogmatically to this common knowledge as a fact. He refers to it by assuming in advance the given facticity of anxiety itself. He adduces or invokes this given facticity, as the assumed common knowledge of an anonymous anxiety we all share or have in common. Yet, by presenting anxiety itself in this way, as what is present for us without ever being presented, Freud is hardly indulging in gratuitous or extraneous digressions, no more than he is innocently pointing to something entirely obvious. Should we not be surprised to find inscribed here the nominalist prejudices of the modern theoretical subject, of all places in a founding text of the psychoanalytic tradition? Does this nominalism not also rely upon the presumed "objectivity" of thought, upon that thought which finds its objects already constituted for it, given in advance? If the problem of anxiety names a discourse and belongs to a tradition, if it appears with and within a history, it is unclear how the appearance of anxiety itself would be accounted for historically. ${ }^{13}$ It is simply taken for granted that there is something called "anxiety itself,"

13 Freud appears to assume, however, in Darwinesque fashion, that the experience of anxiety is also rooted in a preindividual memory, as an embodied, inborn trait that is inherited and acquired from the prehistory or Vorgeschichte of the human species. See, for example, FSA I, 383, and FSA VI, 274. 
which has appeared and continues to appear for everyone as the same and in the same way. Anxiety repeatedly and always appears to each of us as itself from out of ourselves, since, without anything having to be said and without anyone ever being able to say anything, everyone already knows (or supposedly knows) what goes by this name, even if they are in the habit of speaking about it improperly or incorrectly, by mislabeling what they nevertheless already know.

We are simply referred to this generic, anonymous anxiety without any more precise determinations or qualifications. Freud tells us only that we all share this affective condition. There is no indication that the appearance of anxiety itself calls for any such clarification, that there is any need to account for it by means of distinctions which elsewhere appear to be fundamental. For example, there is no mention here at all of the way in which one's perspective or role might bear upon a possible understanding of anxiety, that it appears differently depending on whether it is examined and interpreted from the position of the analyst or merely suffered by the patient, ${ }^{14}$ or that it means one thing to the uninitiated lay person but something else to the expert. 15

Moreover, the problem of anxiety, as Freud understands it, confronts us with a plurality of differing and seemingly heterogeneous anxieties. It concerns not only the various ways in which anxiety manifests itself as a disorder (associated with various neuroses, such as hysterias and compulsions) but also includes how anxiety, as such a

\footnotetext{
14 For example, in an earlier lecture Freud discusses a certain difficulty associated with what he calls "the foundation of psychoanalytic therapy," the discovery that, as soon as unconscious processes are brought to consciousness (or become known), the symptoms afflicting the patient lose their power and must vanish. The difficulty which arises here concerns the actual manner in which this knowldege must be arrived at if it would be therapeutically transformative. It concerns the way in which the unconscious meaning of the symptom must be made conscious, if this knowledge is to have any effect. It does not suffice for this knowledge to be simply conveyed to the patient, as if it were only a piece of impersonal information. Rather, the patient must come to such knowing themselves, must make it their own. Freud thus tells us: "Wissen und Wissen ist nicht dasselbe; es gibt verschiedene Arten von Wissen, die psychologisch gar nicht gleichwertig sind[...] Das Wissen des Arztes ist nicht dasselbe wie das des Kranken und kann nicht dieselben Wirkungen äußern. Wenn der Arzt sein Wissen durch Mitteilung auf den Kranken überträgt, so hat dies keinen Erfolg." (FSA I, 280)

15 In this regard, it would be worth exploring how Freud's use of Vertrautheit relates to his use of kennen, kennenlernen and Kenntnis. See, for example, the beginning of the sixteenth lecture which marks the transition from an examination of errors and dreams to an investigation into neurotic pathology. With respect to dreams and errors, one can appeal to "gesunden Menschenverstand." But when it comes to the interpretation of neurotic disorders, the audience must depend upon what Freud communicates to them: "Das Erscheinungsgebiet der Neurosen ist Ihnen aber fremd; insofern Sie nicht selbt Ärtze sind, haben Sie keinen anderen Zugang dahin als eben meine Mitteilungen, und was hilft das beste Urteil, wenn die Vertrautheit mit dem zu beurteilenden Material nicht dabei ist" (FSA I, 245). Compare this to the passage at the beginning of the 1933 lecture on anxiety already discussed in note 9: the phenomena related to anxiety are the "most familiar," vertrauteste.
} 
collection of multifarious disorders, is to be related to so-called normal or real anxiety. The problem demands that all these divergent senses of anxiety be accounted for as a whole, that they be clarified both in relation to one another and in their way of distinguishing themselves. As the supposed anxiety of common sense, which is presumed to be utterly common to everyone, anxiety itself would also have to include every individual anxiety. But how are we to assume from the very beginning - as the prior condition from which the problem of anxiety arises - such a comprehensive and undifferentiated sense of anxiety? If anxiety itself must be able to accommodate the disparate senses of anxiety, by including within itself all the variable and idiosyncratic ways in which anxiety comes to appearance as a disorder, it appears as a solution before the problem it solves can be posed.

Most puzzling of all in this regard is how this general sense of an original anxiety would accommodate the basic distinction between pathological and so-called healthy anxieties. Anxiety does not become a problem only as it comes to manifest a disorder, since the problem first of all concerns how anxiety itself is to be related to its actual, particular manifestations. How, then, does so-called real anxiety appear as an anxiety in the same way that neurotic anxiety appears as an anxiety? Are those suffering from neurotic anxiety not familiar with real anxiety, even when they do not know whether their own anxiety is real? And does anxiety itself, being the most common experience, not have to refer to both normal and neurotic anxiety, even to every possible sense of anxiety? Or are we to suppose only that the divergent senses of anxiety are related as nothing more homonyms? "One would like to believe that we are dealing with entirely disparate things, yet in the sensation (Empfindung [sic!]) there is no way to distinguish real and neurotic anxiety" (FSA I, 391). ${ }^{16}$

资

Before any answers to these questions might be ventured, it has to be noted that there is something deeply misleading, if not even disingenuous, in Freud's introducing

\footnotetext{
${ }^{16}$ It becomes clear that Freud understands the posing of the problem of the anxiety, at least in this lecture, to hinge upon a clarification of two basic questions: How can neurotic anxiety be related to real anxiety (as the reaction to a danger)? And how is neurotic anxiety to be understood? See FSA I, 387. At a later point in the lecture, he admits that the first question (or task) "appears to be even more difficult to resolve." See FSA I, 391.
} 
anxiety itself only to declare that it needs no introduction. We are easily duped by this double gesture which presents anxiety itself only to withhold it, by withholding its presentation, by both presenting and withholding it at once. The deception lies in the actual wording which distracts us from the unpresentability of anxiety itself by suggesting that Freud is only choosing to forego one stratagem in favor of another, that he is merely refraining from the presentation of what he otherwise could still present.

The actual effect of this sleight of hand is nearly imperceptible. A most subtle and ambiguous gesture distracts us, allowing Freud to conceal what he does in plain sight. Our attention is drawn momentarily to something supposedly irrelevant, to what is deemed unnecessary, unneeded, needless. Anxiety itself appears to be thereby dispensed with. A question is decided before it has been raised, put to rest without being raised. We are asked to focus instead upon the problem of anxiety, to attend to the posing of that very problem which anxiety itself comes to present. By no means, then, does Freud overlook or simply ignore anxiety itself. He does not fail to account for it, if this means leaving it entirely out of account. So little can it be said that he neglects anxiety itself that, on the contrary, he appears to go out of his way to assure us of our prior acquaintance with it, as though he would make us aware of what we supposedly already know. He assures us that we have no need to be introduced to anxiety itself, no need for its presentation, even though, being already acquainted with it, we should have no need for such assurances. Here, then, Freud no more fails to introduce anxiety itself than he fails to address the need to introduce it.

We catch sight of the misdirection, of what is covered over, not from what Freud actually says but by also considering what he leaves unsaid, by attending to what he is able to leave unsaid by virtue of what he does say. Anxiety itself does not go unmentioned; it is not left entirely out of account but referred to as though it were clear to everyone, already in our possession. Freud thus first gestures toward the presentation of anxiety itself as if it were an actual possibility, only then to set it aside. He deems that presentation unnecessary as one who is able to forego it, who is actually able to not present it because in the first place he could present it. The question of anxiety itself, the question of its strange unpresentable appearance, is, then, not simply neglected. Freud 
covers over this question by appearing to have addressed it, disregards it by the way in which he appears to take it up. He forgets to ask the question by assuming its answer. Because there is no need to account for the appearance of what is already clear, for its way of appearing, there is also no need to question whether or how we would be able to account for that appearance, no need to address how we would begin to account for it, that is, by presenting it.

The question of anxiety, the question of its most questionable appearance, as this question would concern our own inability to present or account for that appearance, is rendered moot, set aside and passed over, for the sake of what is needed more urgently, to move on to the problem of anxiety. We never get around to asking how we would present anxiety itself, never have to ask whether it can be presented, precisely because in the first place there is no need to ask. The question which concerns our own ability to respond and account for ourselves from our own experience, precisely as we would find ourselves claimed both by this experience and by the need to account for it, to respond for it in an accountability to it, never arises. But this question is not merely neglected; it is actively disregarded, even repressed. Freud does not introduce anxiety by saying that it introduces itself without being introduced. We are told not that it cannot be presented but that there is no need to present it. And by introducing anxiety itself in this way, Freud goes out of his way to avoid the question, by insisting from the beginning there is no need to ask it. He presents anxiety as what needs no presenting in order to avoid accounting for its unpresentable appearing.

Yet the crucial point here, once again, is that Freud himself does not begin with anxiety as a problem. He does not begin by presenting that problem, no more than he simply ignores anxiety itself. On the contrary, he begins by making room for the problem or, more precisely, for its posing, by shutting down and containing every possible concern with anxiety itself. The posing of the problem becomes possible, in other words, not simply through the introduction of anxiety itself but by virtue of the way it is introduced. By introducing it as what needs no introduction, Freud allows himself to insist preemptively upon its unquestionable self-evidence. And therein lies the trick. 
We arrive at the same conclusion if we consider that the locution, "I have no need to...," almost always assumes the possibility of doing the very thing it deems unnecessary. The phrase serves to indicate not the sheer impossibility of some undertaking but only its inexpediency, where the relative expediency of a course of action always refers, at least implicitly, to some unattained but attainable end. Something otherwise possible is deemed unnecessary, unneeded. It appears useless precisely as an instrument or as a means, but only under the assumption of some given project. Yet what appears unnecessary in this way is always also configured within an open situation, by the question of what that situation might demand or promise, along with the various alternatives available within it, as these alternatives present themselves as actual possibilities. What appears without being needed, what is deemed unnecessary, remains, then, a thoroughly situated determination. It has its sense only in distinction from what imposes itself upon us with the urgency of a given need. What is deemed unnecessary always belongs to such a situation, by appearing within it, as that situation continually solicits our response and even remains undecideable without that response.

In this sense, to insist that something is unnecessary amounts to confessing that it is not worth pursuing, but not simply because it lies beyond our reach, nor even because it lacks intrinsic value. The sense of what we judge to be unnecessary is always configured by the way in which a situation is taken up by us, by the manner in which we direct ourselves toward it practically, concerned with what it calls for. But, for this very reason, we would never question whether something is needed, or insist upon its inexpediency, if it did not already present itself as one possibility among others. It thus bears repeating: being able to not do something differs decisively from not being at all able to do it, since it requires that one also be able to do it. And no one decides to not do something, even something unnecessary, without first being able to do it. If doing or not doing are to present real options for me, if they would demand that I choose between them, then I must choose one over the other, and so, must also begin by affirming both as actual possibilites. In our everyday affairs we are, of course, continuously occupied with what is up to us, with what we assume to be within our reach, so much so that we no more bother to insist upon the needlessness of what cannot be done than we ever take issue with the 
need to do it. And, to be sure, we never have in our possession everything we may need, but neither do we ever need everything we do not have. Pointing out the needlessness of what is impossible, as though one were able to relinquish what cannot be or surrender what one does not have, makes as much sense as attempting to enforce its prohibition. ${ }^{17}$

Freud does not explicitly insist upon the presentability of anxiety itself. He does not declare that its presentation would be possible, only unnecessary. Yet by telling us that there is no need for this presentation, he is able to suggest its possibility without having to insist upon it; he is able to avoid the question of its presentation. But, strictly speaking, the issue is left open. Freud only tells us that the presentation of anxiety would be inexpedient, it would serve no purpose. If we were to present it - assuming, of course, that we would be able to present it - that presentation would not contribute in any way to our understanding of anxiety, would not aid us in finding a solution to the problem anxiety presents.

Nevertheless, on Freud's own terms, anxiety itself not only does not need to be introduced, it cannot be introduced. It needs no introducing precisely because it has always already introduced itself, already presented itself to us from out of ourselves, without being presented and without needing to be presented. And, by always first introducing itself to us in this way, it also cannot be introduced by anyone. No one first learns about it from another and it cannot be presented to anyone by another, neither to those who have already made its acquaintance - namely, each of us, since we already know it - nor, even, to those who may have yet to be acquainted with it, since it belongs to the self-showing of anxiety itself that it always come to everyone from out of themselves. It belongs to its way appearing (as itself) that it must first show itself to us in this way, that is, not by being announced by another or delivered over from another, but by first coming to us from out of ourselves. Its presentation, therefore, is not only unnecessary, but impossible.

17 This is not meant to deny the paradoxical urge or need to prohibit impossibilities. As Žižek has shown, we confront such prohibitions everywhere, for example, in Kant's moral law (especially in Heine's parodizing of that law - Du kannst, denn du sollst!), in Wittgenstein's imperative that we keep silent where we are unable to speak, and even in the Catholic position on human cloning (the presumed impossibility of which does not detract from its immorality). In fact, if one proceeds "onto-theo-logically" - from what Kundera has called the "categorical agreement with being" - evil is both impossible (i.e., nothing) and also what must first of all remain forbidden. 
We never step outside this condition but always proceed from it. We are always proceeding from the given impossibility of suspending this facticity, namely, as that condition in which we repeatedly find ourselves claimed in advance by anxiety, from out of ourselves and in our pre-acquaintance with it, being already affected by it, such that it cannot be and never is first presented to us, neither by us nor by any other. This is not to say simply that we are always anxious or constantly becoming anxious. Rather, by virtue of our given experience we are always already ready for anxiety, ready to become anxious once again. If we are to make sense of Freud's insistence upon an anxiety which is common and familiar to all of us, we still have to consider how he understands this difference between being always able to become anxious and that affective state or condition which is already an actual anxiety.

次次

How, then, in the first place do we become acquainted with anxiety at all? How does it first present itself to us from out of ourselves, such that our experience of it remains nothing more than a repetition of a given and familiar anxiety, a return or reprise which only confirms again the anxiety we have already come to know? How do we first come to ourselves, to our very life, being always already ready for anxiety, in an anticipation of its return?

It cannot be denied that this question receives no unequivocal answer. Freud's way of answering it appears at first to require only the recognition of something entirely obvious, even undeniable, namely, that the conditions of human life, like those of all life, are perilous. Insofar as we find ourselves confronted with an external world, we inevitably also find ourselves facing real dangers. There is, then, a "real anxiety" [Realangst] which arises as a response or a reaction to some threat and which cannot be dismissed as a merely pathological affliction or a delusional disorder. It distinguishes itself from merely neurotic anxiety by the actual situation which gives rise to it and by the real danger it perceives. Because it appears as a "reaction to the perception of an external danger, that is, to an expected and foreseen harm," we take it to be something "rational" and "comprehensible," an "expression of the instinct [or drive] for self-preservation" (FSA I, $381)$. 
Freud concedes, of course, that the actual situations in which we become anxious vary, since they depend upon both our knowledge and our sense of power over and against the external world and since the encounter with such real dangers always takes place in the encounter with that world. But the anxiety which is concerned with real dangers also does not result from only ignorance or uncertainty. On the contrary, often times it is an advanced knowing (das Mehrwissen) which brings about real anxiety, by allowing us to discern actual dangers which otherwise remain hidden. Real anxiety thus correlates to a perspicacity; it is grounded in a percipience, a perceptivity. The fresh tracks of a deadly animal or the signs of an approaching storm may provoke anxiety, but only to those who know how to see them and can grasp what they foretell. Anxiety, if it is to be real or realistic, is more than an irrational fear of the unknown; it arises from an actual awareness of the world and cannot be accounted for without considering the shifting limits of this awareness. What gives this anxiety its reality is not simply its reaction to a real danger but that this reaction is grounded in an actual perception..$^{18}$

Still, even if the experience of anxiety acquires a certain validity as a response to real dangers, by giving expression in this response to a real situation, it nevertheless remains unclear how anyone gains an advantage by responding to a threat in this way. It is unclear, in other words, how real anxiety is to be viewed as a response which actually confronts and engages the reality which provokes it. How does (real) anxiety allow us or enable us to respond more effectively to a perceived threat? What is its actual function? What is accomplished and what are we seeking to accomplish when we become anxious in a dangerous situation? If our presumed aim in such situations is to save ourselves, either by escaping or by subduing the danger which threatens us, how can it be said that anxiety is at all beneficial? Freud thus asks: to what end and in what way is such anxiety purposive or purposeful, expedient, that is, zweckmäßig?

As Freud sees it, however, becoming anxious can hardly count as an effective or beneficial response to a perceived threat, when in general the best response would be "a cool assessment of one's own strengths in comparison to the magnitude of the threat and,

${ }^{18}$ Freud thus observes at a later point in the lecture that real anxiety is uncommon in children. "Von richtiger Realangst scheint das Kind wenig mitzubringen." In actually dangerous situations, the child shows no fear, and all the less so the more ignorant the child is. FSA I, 393. 
on this basis, a decision as to whether flight, defense, or perhaps even an attack, provides a greater chance for a good outcome" (FSA I, 381). To be sure, when what is needed is deliberate and decisive action based on strategic calculations, the panic stricken and frenzied blindness of a paralyzing anxiety is not only unproductive but potentially counterproductive, not only ineffectual but even detrimental. Even so, this claim also has its limits. For example, by stressing the practical advantages of assessing in advance the risks and possible gains of a course of action, Freud utterly neglects another possibility, that dangers may also be faced with a courage exceeding the assurances of strategic calculation, not to mention that we may also find ourselves at times seeking out danger rather than avoiding it. In any case, insofar as anxiety makes us less capable and may even leave us entirely incapacited, Freud concludes that the optimally expedient response to a threatening danger would always be the least anxious: "everything that happens would be accomplished just as well and probably better were there to be no becoming anxious (alles, was geschieht, würde ebensowohl und wahrscheinlich besser vollzogen werden, wenn es nicht zur Angstentwicklung käme)" (FSA I, 382). And, again: "it is thus tempting to maintain that becoming anxious is never something expedient (Man fühlt sich also versucht zu behaupten, daß die Angstentwicklung niemals etwas Zweckmäßiges ist)" (FSA I, 382).

Anxiety, even when real, thus proves to be a debilitating and deleterious affect. It takes possession of us, comes over us, in dangerous or threatening situations, but only to make matters worse; rather than coming to our aid, it adds to our difficulties. Although real anxiety is a reaction to a real situation, this also exposes how as such a situated reaction it remains a failed response. It fails in response to what that situation actually calls for. Real anxiety, then, is not at all something rational, comprehensible, purposive. On the contrary, it proves to be inexpedient, irresponsible.

Yet there is also something odd here. At first it is not at all clear why Freud in these passages no longer speaks of anxiety only as an affective state or condition but now suddenly introduces a new and somewhat unusual term, die Angstentwicklung, which I 
have just translated as "becoming anxious."19 The reason for introducing this new term, which speaks of a "development" or an "uncoiling," remains unclear until Freud begins to consider more explicitly the emergence of anxiety, not only by focusing upon the situation from which it emerges but also by relating anxiety to that situation, that is, by considering it not as a mere state but precisely as it emerges or comes to be. The sense of this new term, "becoming anxious," becomes clear only as Freud begins to consider anxiety neither merely as a given state nor only as a thoroughly situated moment, but instead as a temporalized situation comprising a plurality of differing and related moments. The "anxiety-state" (Angstzustand) is not merely an "affect-state" (Affektzustand) but is better understood as a situated "becoming anxious" (Angstentwicklung), since it appears as only one moment within what Freud calls the "anxiety-situation" (Angstsituation). What is striking here is this shift in perspective and what it brings to light. We acquire a better understanding of anxiety neither by only considering the affective state alone, in isolation, as that mere affect which occasionally comes over us, nor, even, when we consider this affective condition as a reaction to the situation within which it appears. Instead, the experience of anxiety takes place and takes time. This event is better understood if we direct ourselves toward it with respect to its encompassing situation, as toward that horizon within which distinct moments and various possibilities come to be organized and related to each other.

Anxiety itself, introduced at first as an affect or as an affective condition, proves to belong to a situation. The affect appears as a situated moment, that is, as only one moment among others. It appears within a situation but without defining or exhausting that situation. And, included within this situation, are also other constitutive moments which remain distinct from the affective state itself; while they are related to a possible becoming anxious, these also remain irreducible to that state. At first, the situation of anxiety appears to consist of three basic moments: Freud says it is (1) a reaction to (2) the perception of (3) a threatening danger. Yet, we also discover that, as that state or affect in which we actually become anxious, this reaction also proves to be inexpedient and

19 My reasons for departing from Strachey's 'standard' translation, "the generation of anxiety" or "generated anxiety," will become clear in what follows. 
irresponsible. Freud thus invites us to examine the anxiety-situation more closely; we have to break it down or take it apart more carefully.

Freud observes, in particular, that this reaction does not begin simply in an anxious state. It is not already from the beginning anxious but must become anxious. The first thing we discover is not the affect as such (the state in which we actually become anxious) but, prior to this becoming anxious, there is a "readiness for danger" (die Bereitschaft auf die Gefahr), or an "expectant readiness" (Erwartungsbereitschaft), which manifests itself physically or physiologically "in a heightened sensory attentiveness and motor tension." Although this readiness prefigures the inexpedient affect, it also prepares us for what is most expedient, namely, that action which takes up the threat and actually responds to it. And, by enabling us to act more readily and more effectively to what threatens us, by allowing us to be open to our situation in its indeterminacy, this readiness appears to be unconditionally advantageous. "What emerges from this readiness is, on the one hand, a motor action [...] and, on the other hand, what we sense as the condition of anxiety (was wir als den Angstzustand empfinden [sic!])" (FSA I, 382). What we sense as a state of anxiety is anticipated by another moment, by a heightened awareness and a certain readiness, which prepares the way for that anxious state without yet necessitating it.

A readiness (or preparedness) for danger is introduced here as the prior condition from which anxiety arises: it establishes itself prior to the onset of the affective condition itself, such that without it that affect would never come over us. And this precondition, as a mere readiness, only comes into view as Freud attempts to account for the experience of anxiety more carefully, not only by examining its affect as an isolated moment (as a mere reaction to danger) but by also considering the larger movement or broader horizon within which that affective moment is situated and made possible. As the condition which precedes the affect, which in its anteriority thus conditions the emergence of the affect precisely as we are conditioned by it - that is, as the affect comes to claim us in and as an affective condition - this readiness is not already the actuality of anxiety (as an affect) but rather an actual readiness for it, an open availability to that affect as an possible actuality. 
We are referred here, then, to two distinct but related moments: there is, on the one hand, the condition or precondition of an anxious readiness which is not yet anxiety (as an affective condition) and, on the other hand, that affective condition which is anticipated in this readiness and for which it is already anxiously ready. And yet, as distinct positions or perspectives, these two moments not only distinguish themselves from each other but also punctuate and define a movement to which they belong but which for its part remains fundamentally irreducible to them.

This movement remains excessive to the positions marked by these singular moments inasmuch as it spans the transition between them, the gap by which they differ, as the very passage by which one moment would be connected to the next. Such a movement names precisely that passage in which a mere readiness for anxiety (as a possibility) becomes the affective condition or state in which we find ourselves claimed by an actual anxiety. How, then, are we to account for such a transition or passage, precisely as it refers to the coming into being of an actual anxiety, even as "anxiety itself," if we find ourselves already affected by anxiety as a mere possibility? Is it not this very possibility, even as the possibility of possibility as such - namely, in a readiness for it which first allows for every being anxious and which is already an anxiety before all possible anxiety?

In any case, any attempt at accounting for this excessive and still unaccounted for movement (from the merely possible to the actual) would have to begin with what must remain undecided in any mere readiness for anxiety as a presumed actuality. Such an attempt would have to begin, in other words, by asking how any such readiness must harbor or preserve within itself an essential indecision, insofar as it has yet to become the anxiety it would also be ready for. Even if this readiness does establish the prior condition from which anxiety arises - as though, by anxiously anticipating the actual irruption of that affect, it were to find itself already claimed and affected by that anxiety nevertheless, this same readiness must also be able to distinguish itself from the affect, precisely in its readiness for it. Thus, even as this readiness must find itself solicited by the affect it anticipates, it must also remain somehow anterior to that affect, and must 
distinguish itself from that affect in this anteriority - if, that is, it would be able to respond at all to that very solicitation.

Between the mere readiness for those dangers which would make us anxious and the actual anxiety which has already submitted reactively and affectively to such danger, there is, then, still another, more decisive moment, in which our response to anxiety as a possibility comes to be decided. Freud assumes this decision while also passing over it. He assumes that such a decision comes to be made but without at all accounting for either the decision itself or his assumption. Our readiness for danger, he tells us, gives rise to two different possible outcomes which remain at odds with each other. There is the possibility of an action which responds to its situation (whether through fight or flight) and there is also the possibility of reacting to that same situation with the debilitating affect of anxiety. It is important to note that from the position occupied by the readiness itself, within its situated perspective, anxiety does not so much appear as a problem to be solved or resolved, through a mere understanding, so much as it would be decided by our response, precisely as it calls us to act in response to it. ${ }^{20}$ On Freud's own terms, anxiety thus appears as a condition which would define us but only insofar as we are also able to respond to it. ${ }^{21}$ As such a condition it would also have to remain undecided, being still undecided or still to be decided, if not for our involvement with it and our response to it. Moreover, this response would always remain in advance an unjustified and seemingly unjustifiable act, which would first have to justify itself through its very enactment, by being performed.

The affect, as a becoming anxious, appears as the inexpedient and irresponsible interruption of a possible action in response to its situation, just as an expedient response

\footnotetext{
${ }^{20}$ That this decisional moment belongs to the movement of anxiety itself is also confirmed in the 1933 lecture, although here Freud speaks of this moment as an anxiety-reaction: "Aus dieser entwickle sich die Angstreaktion. In der seien zweie Ausgänge möglich. Entweder die Angstentwicklung, die Wiederholung des alten traumatischen Erlebnisses, beschränkt sich auf ein Signal, dann kann die übrige Reaktion sich der neue Gefahrlage anpassen, in Flucht oder Verteidigung ausgehen, oder das Alte behält die Oberhand, die gesamte Reaktion erschöpft sich in der Angstentwicklung, und dann wird der Affektzustand lähmend und für die Gegenwart unzweckmäßig” (FSA I, 518). See also the similar: "Dann sind mehrere Reaktionen möglich[...]" (FSA I, 525). Compare also the passage at FSA VI, 275 .

${ }^{21}$ In this context it is worth pointing out that Freud draws a connection between a person's "character" and the established "reaction-formations" by which anxiety comes to be dealt with (FSA I, 525). And although he does also come to speak of an "anxiety of conscience" (Gewissensangst), by which the ego relates to itself via the super-ego, he also insists that even such moral anxiety must be considered as it originally results from a real anxiety.
} 
requires that a debilitating anxiety be precluded. Prior to becoming anxious there is, then, either another moment of anxiety or a moment which actually prepares us for danger, but which, in any case, cannot be decided as a response until it actually does respond. It must decide itself in response to what remains its open situation, not only as that situation solicits this response but as it remains, for its part, undecidable without that response. This anterior, pre-anxious moment will have been either itself already another kind of anxiety or that point at which anxiety is first averted, forestalled. In its undecided appearance it is either only a readiness for anxiety (in a readiness for danger) and therefore not at all a becoming anxious or it is itself already an anxious readiness, already no longer merely ready for anxiety but already on its way to becoming anxious. Freud thus immeasurably complicates the anxiety-situation by introducing the question of our response to that situation in the complexity of its temporalized occurrence.

The more becoming anxious recedes into a mere approach, into a signal, the more unimpeded is the conversion of anxious readiness into action and the more expediently does the whole process organize itself. (Je mehr sich die Angstentwicklung auf einen bloßen Ansatz, auf ein Signal, einschränkt, desto ungestörter vollziieht sich die Umsetzung der Angstbereitschaft in Aktion, desto zweckmäßiger gestaltet sich der ganze Ablauf) (FSA I, 382). ${ }^{22}$

Freud introduces in this passage a constitutive moment which anticipates becoming anxious, which precedes the actual entering into an anxious state. The crucial distinction is drawn between anxiety as Angstbereitschaft and anxiety as Angstentwicklung. As a precondition which conditions the possibility of anxiety as a condition, the readiness for anxiety appears as what is not yet a becoming anxious. However, without yet becoming anxious, this moment also appears as if it were on the verge of an anxious state, already anxiously ready to become anxious. According to Freud, the more this readiness withdraws into a mere Ansatz, into nothing more than a mere disposition or availability, the more it remains a beneficial readiness for danger. As anything more than a mere warning, it already becomes something more than a mere

${ }^{22}$ Compare this to a similar passage in the 1933 lecture. See FSA I, 525. 
readiness. It ceases to be available for what is most needed, the moment of action as an abrupt transition or metábole, the conversion (Umsetzung) into action from an anticipatory readiness. And yet, there is also something strange about this mere readiness which would save the affect from the irreality and irresponsibility of its own hyperbolic and reactive flight. As a mere anticipatory readiness the most realistic moment of anxiety is also entirely indeterminate. By becoming an affect gripped by fear, by something worth fearing, it is as if anxiety already loses touch with reality; it is already on its way to neurosis.

The readiness for danger must therefore always also be a readiness for anxiety, not because danger must always precipitate anxiety but rather because anxiety in its indexpediency only enhances and augments every danger we face. As a readiness for anxiety, this readiness is already anxious before its own anxiety, anxious in the anxiety it knows it already is and can become. In its mere readiness it is also continually ready to become an anxious readiness, already threatened by the anxiety which it harbors within itself and which it already knows. Yet this is also what distinguishes this mere readiness from that dysfunctional affective state which is actually becoming anxious; precisely as a readiness for anxiety it is also ready to act, that is, to respond expediently to danger. Freud thus comes to an important conclusion: "The readiness for anxiety [which is to say, not anxious readiness] thus seems to me to be what is expedient in what we call anxiety and becoming anxious seems to be what is dysfunctional [das Zweckwidrige: not merely inexpedient (unzweckmäßig) but counterproductive, detrimental, disadvantageous]. (Die Angstbereitschaft scheint mir also das Zweckmäßige, die Angstentwicklung das Zweckwidrige an dem, was wir Angst heißen, zu sein)" (FSA I, 382).

粦次次

It thus becomes all the more evident how Freud arrives at this important distinction between anxiety as a mere readiness for anxiety and anxiety as an actual state or affective condition. He is led to draw this distinction because without it real anxiety appears only as an interruptive and irresponsible inexpediency, even as a dysfunctional liability afflicting us at the worst possible moments. Freud is intent upon saving anxiety from its apparent irrationality, from its incomprehensible appearance. 
What makes real anxiety actually realistic, in other words, is not simply that it is grounded in a perception of something real - namely, in the situation of a threatening danger - but, more importantly, that as such a reaction it also enables us to respond to what the situation calls for, that we are able somehow to act in response to it. The affective state does not appear merely as a reaction to a perceived danger but its emergence can be traced back to that anxiety-readiness which has yet to become anxiety, which as a mere readiness is never merely anxious but also ready to act. The affect emerges from this preanxiety which is not only able to become anxious but also actually able to not become anxious, which remains able to act to the degree it continues to resist its own anxiety, to resist it precisely by anticipating it. The affect emerges from an anxiety which is not (yet) anxiety and has not (yet) become anxious. It emerges from that pre-anxious moment which remains distinct from becoming anxious as long as it remains not only still rationally and purposively directed toward its situation but also an anticipatory readiness for becoming anxious.

But we also witness here the problematizing operation which demands that the otherwise irrational and inexpedient appearance of anxiety prove itself to be somehow rational, expedient, purposive. This problem is then solved by including within anxiety another kind of anxiety, that mere readiness which as a liminal moment distinguishes itself from the affect by serving as a kind of protection from its irrational and irresponsible excesses. The problem itself demands that another possibility be opened up and preserved within the danger-situation. Anxiety remains real insofar as it remains this readiness, being ready in the ability to resist becoming anxious. As a readiness for danger, this mere readiness for anxiety is also not anxiety, since it must also protect itself against becoming anxious. Paradoxically, anxiety becomes real precisely by not becoming anxiety, just as the problem of anxiety presents itself only as another question is silenced, only as the question of anxiety itself in its unpresentability is covered over and only as this covering over is itself covered over. Yet it is anxiety itself, in its incomprehensible and unpresentable inexpediency, which continues to call for our response and in this solicitation to confront us with a much more abysmal (ir-)responsibility. 
Freud makes it unmistakably clear that by "becoming anxious" he means to refer to anxiety as an affective state. But the more crucial point here is that this state or condition now refers to only one possible sense of anxiety, one way anxiety appears within a plurality of other senses or other ways of appearing. The affective state thus does not capture the indeterminacy of what is called anxiety. And the difficult passage with which we began has now acquired a richer sense. "A certain ambiguity and indeterminacy in the usage of the word 'anxiety' will not have escaped you. For the most part one understands by anxiety the subjective condition, the state one enters into through the perception of 'becoming anxious', and this state or condition is called an affect ([...] den subjektiven Zustand, in den man durch die Wahrnehmung der 'Angstentwicklung' gerät, und heißt diesen einen Affekt)" (FSA I, 382).

Freud places his own neologism, Angstentwicklung, in scare quotes in order to emphasize that it designates but one limited perspective, anxiety in a particular sense, namely, as an affect or affective state. But we also discover something else. Although the affect is a reaction to a perception (of a danger), it is also itself something perceived. It is a self-perception or a perception of oneself being affected, of oneself affecting oneself in this self-perception. We enter into the state of anxiety by perceiving ourselves in the affect and thus by finding ourselves affected. Anxiety begins not as a mere reaction to the perception of something external (a threat); it begins as the affect itself comes to be perceived by the one who is affected, by that one who thus perceives themselves becoming anxious. Yet we would never perceive ourselves in this way, would not find ourselves delivered over to the affect as this "subjective state," if we were not in the first place already ready for anxiety. The perception of the affect - which is also its auto-affectivity or the affect as this self-perception - does not first establish but presupposes our prior acquaintance with it.

An answer to the original question thus continues to elude us. We become anxious only if we are ready for anxiety, already ready to become anxious once again, only if we are already familiar with anxiety itself such that we never come to be introduced to it, but only return to it, once again. We are delivered over to this self-perceiving auto-affectivity as we find ourselves affected, but only as the perception of something already perceived, 
as the repetition of that original perception. But if this perception is constituted only as a repetition or reiteration, how, then, did we ever first come to be affected? How do we ever first perceive the affect and first become affected by that perception, when neither affect nor perception can emerge without a more original readiness for anxiety?

Freud takes up this question indirectly. He arrives at an answer but he follows a circuitous route, namely, by first asking how the affect as a perception can be something both perceived and perceiving. On the one hand, the perceptual character of the affect can be considered dynamically. Like all affects it is organized by multiple and interrelated moments; it is an amalgamation of discrete moments, "something very composite" (etwas sehr Zusammengesetztes). "An affect," says Freud, "first of all comprises definite motor innervations or discharges and then, second, certain sensations (gewisse Empfindungen), the latter being of two kinds, the perceptions of the transpired motor actions and the direct sensations of pleasure and displeasure which give the affect, so to speak, its fundamental tone" (FSA I, 382-3). On the other hand, however, Freud concedes that one never reaches this basic tone, tuning or attunement (Grundton), which is the distinctive and distinguishing feature of the affect, so long as one proceeds only from the disconnected parts to the whole. Without saying so directly, Freud suggests here that a perception is never the result of a synthetic act which somehow cobbles together a perceived unity from more disparate elements. One has the sense, he says, that this mere "enumeration does not get at the essence of the affect." The affect, in other words, must already be given to us as an experience before we are able to encounter it perceptually, even before we are able to consider it as a manifold of differing moments: "In certain affects one believes to glimpse into something deeper and to recognize the kernel which holds the ensemble together," namely, "the repetition of a definite meaningful experience" (die Wiederholung eines bestimmten bedeutungsvollen Erlebnisses) (FSA I, $383) .23$

${ }^{23}$ Freud himself offers his own summary of this passage in the 1933 lecture: "Wir haben gesagt, Angst sei ein Affektzustand, also eine Vereinigung von bestimmten Empfindungen der Lust-Unlust-Reihe mit den ihnen entsprechenden Abfuhrinnervationen und deren Wahrnehmung, wahrscheinlich aber der Niederschlag eines gewissen bedeutungsvollen Ereignisses[...]" (FSA I, 517). 
The unity of anxiety as a perceptual experience, the fundamental tone or attunement it establishes, cannot be derived merely from the aggregation of its manifold parts. As a perception which is not only perceptive (not only the original disclosure of a mortal danger) but which is also itself something perceived (a self-perceiving perception), the affect is no mere sensation but also a repetition of an experience: we become anxious only because we are already anxious, ready to become (once again) anxious. As the repetition of a prior experience, anxiety also persists as the original experience of this repetition. And yet, if we never become anxious without being already ready for anxiety and cannot be ready for it without having already become anxious, how do we then first find ourselves ready such that we can become anxious? Where and how does anxiety begin? Where do we find original anxiety? How is it that we are, each of us, already familiar with anxiety itself, such that in its incommunicable and unimaginable unpresentability it neither needs nor can have any introduction? Freud's answer is as astonishing as it is, perhaps, undeniable:

We believe we know which primeval impression returns as a repetition in the anxiety-affect. We hold that in the act of birth there is constituted that grouping of displeasures, discharges and bodily sensations which has become paradigmatic for the effect of a lifethreatening danger and which ever since comes to be repeated by us as the condition of anxiety. (Beim Angstaffekt glauben wir zu wissen, welchen frühzeitigen Eindruck er als Wiederholung wiederbringt. Wir sagen uns, es ist der Geburtsakt, bei welchem jene Gruppierung von Unlustempfindungen, Abfuhrregungen und Körpersensationen zustande kommt, die das Vorbild für die Wirkung einer Lebensgefahr geworden ist und seither als Angstzustand von uns wiederholt ist.) (FSA I, 383) 24

\footnotetext{
${ }^{24}$ In the 1933 lecture, while distancing himself critically from the work of Otto Rank, Freud also claims to be in agreement with its basic doctrine, namely, that the experience of birth is the paradigmatic experience of anxiety which prefigures all subsequent danger-situations (FSA I, 523). See Otto Rank, Das Trauma der Geburt und seine Bedeutung für die Psychoanalyse (1924). This very claim is already found in an addendum from 1909 to Traumdeutung (1900), in which Freud reflects upon a peculiar anxiety, the fear of being buried alive. This life beyond death, he says, projects into the future that uncanny life which also precedes birth. The connection between birth and death is thus opened up in an anxiety which encounters an uncanny life surpassing both its beginning and its ending. See FSA 2, 391. Although
} 
The original trauma, as that traumatic event within life, by which life is first exposed or delivered over to its own anxiety and to itself in this anxiety, such that it remains henceforth receptive to this affective condition as its own innate anxiety, from out of itself - that is, as an intrinsic and always anticipated possibility which haunts every possibility - is nothing other than the very entrance into this life. The birth into life is already a birth into anxiety. What first threatens life, making it essentially anxious, always already ready for anxiety, is nothing other than the inceptive event of life itself, the event of life coming to life, to itself in its birth. The mortal danger of life thus begins, Freud tells us, with its own natal beginning, and it is this very natality which is already the expectancy or anticipation delivering it into its mortal fate.

A responsibility for this natal, mortal anxiety would then amount to being able to respond for oneself in one's own being born, as a being thrown toward one's own death. Anxiety would be the original response to life, by which life responds to itself, to its own event, being thus affected by itself in response to its own mortal natal appearance, while also establishing the very condition or precondition of every possible response within that life. Being born, each of us thus finds ourselves already anxious, from out of ourselves, only because, being born, we are also first of all able to respond for ourselves - to respond for ourselves, that is, by also responding for anxiety itself.

(C)2021 Peter Warnek

Freud grants that new dangers certainly arise within life (FSA I, 528), even outlining the developmental stages of human life as they would each be defined by distinct traumatic experience (FSA I, 523-4), the event of birth, as "die allererste Angst" (FSA I, 517), also remains the fundamental paradigm, prototype or model (Vorbild) according to which all subsequent danger is assessed. The same point is made in Hemmung, Symptom und Angst (FSA VI, 281), where Freud also presents in more detail how his position differs from Rank's. See VI, $276 \mathrm{ff}$. and also $289 \mathrm{ff}$. 